\title{
Predicting the potential global distribution of diosgenin-contained Dioscorea species
}

\author{
Liang Shen ${ }^{\dagger}$, Jiang Xư ${ }^{\dagger}$, Lu Luo, Haoyu Hu, Xiangxiao Meng, Xiwen Li ${ }^{*}$ and Shilin Chen ${ }^{*}$
}

\begin{abstract}
Background: Diosgenin, mainly extracted from wild diosgenin-contained Dioscorea species, is a well-known starting material of steroidal and contraceptive drugs. However, due to large market demand and increasingly ecological damage, wild Dioscorea species resources available have been gradually declining. Therefore, identification of new potential ecological distribution of diosgenin-contained Dioscorea species is necessary for diosgenin production.

Methods: In this study, a large occurrence dataset (1808 data points) of diosgenin-contained Dioscorea species was obtained from Eastern Asia, Southern North America and Southern Africa. Along with the data for six critical environmental parameters and one soil factor, Geographic Information System for Global Medicinal Plant was applied to predict the potential suitable distribution of Dioscorea species.

Results: The results showed that the potential distribution of these Dioscorea species covered a wide field, and that new ecological suitability areas were mainly distributed in the central region of South America, the southern part of the European and coastal region of Oceania. Jackknife test indicated that annual precipitation and annual mean radiation were the important climatic factors controlling the distribution of Dioscorea species.
\end{abstract}

Conclusions: The suitable areas and critical climatic factors will serve as a useful guide for diosgenin-contained Dioscorea species conservation and cultivation in ecological suitable areas.

Keywords: Dioscorea species, Diosgenin material, GMPGIS, Potentially suitable areas, Climate characteristics

\section{Background}

Diosgenin is a versatile starting material for the manufacture of steroidal drugs, and it is mainly extracted from Dioscorea species [1]. Steroidal has strong anti-infection, anti-allergic and other pharmacological effects which plays an important role in the treatment of rheumatoid arthritis, heart disease, peptic ulcer disease, etc. [2]. Diosgenin has also been prescribed as an oral contraceptive with large market demands in recent years. There are 137 kinds of Dioscorea species containing diosgenin, 41 kinds of which contain over $1 \%$ diosgenin with great utilization value [3]. However, their resources have been declining

\footnotetext{
*Correspondence: xwli@icmm.ac.cn; slchen@icmm.ac.cn †Liang Shen and Jiang Xu contributed equally to this work Institute of Chinese Materia Medica, China Academy of Chinese Medical Sciences, Beijing 100700, China
}

quickly due to excessive harvesting, and some species are even getting nearly extinct. Nevertheless Dioscorea became a major source to produce steroid hormone due to the failure of accomplishing chemical synthesis of steroids [4]. In India, approximate 100\% production of steroidal drugs is based on diosgenin material from Dioscorea species [5]. Therefore, it is necessarily needed to explore approaches in conservation and cultivation of diosgenin-contained Dioscorea species to obtain diosgenin materials.

Recently, booming market demands boosted the expansion of introduction and cultivation of Dioscorea species worldwide. China and Mexico are the two main production countries, which account for $67 \%$ of diosgenin yield with the richest Dioscorea resource in the world [1]. However, the yield and quality of diosgenin was declined due to the lack of high-quality germplasm, unknown

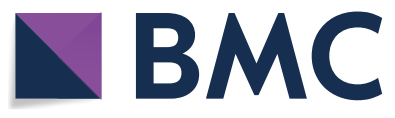

(c) The Author(s) 2018. This article is distributed under the terms of the Creative Commons Attribution 4.0 International License (http://creativecommons.org/licenses/by/4.0/), which permits unrestricted use, distribution, and reproduction in any medium, provided you give appropriate credit to the original author(s) and the source, provide a link to the Creative Commons license, and indicate if changes were made. The Creative Commons Public Domain Dedication waiver (http://creativecommons.org/ publicdomain/zero/1.0/) applies to the data made available in this article, unless otherwise stated. 
suitable plant region and shortage of useful technology [6]. As far as we are concerned, there still exist some Dioscorea species cultivated in rural China, what remains confusing to us is that whether they can be used as diosgenin source or not has not been testified yet [7]. Understanding the requirements of habitat conditions of these Dioscorea species may be useful for managing population recovery and plantation, as well as promoting economic growth. The cultivation methods for Dioscorea species, such as breeding, management, and planting have been discussed by previous reports $[8,9]$. Nevertheless, suitable distribution and ecological requirements of these Dioscorea species remain unknown. Quite a limited number of studies have assessed the distribution patterns of the Dioscorea species, and there was an article about habitats across Bangladesh by the species distribution modeling (SDM) [10]. Additionally, the D. nipponica potential distribution was assessed across Jilin province in China by the MaxEnt. High fitness suitable areas were also identified to concentrate at the central and southern regions of Jilin [11]. Hence, it is essential to conduct conservation and cultivation study on a global scale for Dioscorea species which analyzes ecological factor similarities include climate, soil between the origin and introduction sites and to draw an accurate global cultivation region map.

With the development of network technology, the geographic information system (GIS) is just an ideally digital mapping tool adopted for geospatial database creation, data integration and modeling [12]. GMPGIS can predict the impact of climate on medicinal plants potential distribution model, and the model is verified successfully in predicting the distribution of Panax species [13-15]. It is of great significance to predict the potential suitable distribution of Dioscorea species by GMPGIS with primary ecological factors for their protection and utilization. In this study, we analyzed the potential global suitable habitats of diosgenin-contained Dioscorea species by means of GMPGIS based on six climate variables and soil factor, and mapped the key environmental variables that constrain the geographical distribution of those Dioscorea species by Jackknife test. These results will provide a valuable reference for conservation, introduction and cultivation of diosgenin-contained Dioscorea species worldwide.

\section{Materials and methods \\ Species data}

In this study, ten Dioscorea species were selected in accordance with the principle of higher diosgenin content, crop yield and industrialized application [4, 16-18]. Samples points of Dioscorea species were drawn from main producing areas, wild distribution and historical growing region [13]. Data on the distribution of Dioscorea species were obtained from the following sources: (1) the Global Biodiversity Information Facility Data Portal (GBIF, http://www.gbif.org/); (2) Royal Botanic Gardens, Kew (Kew, http://www.kew.org/); (3) the Chinese Virtual Herbarium (CVH: http://www.cvh.org.cn/); (4) relevant literature and field investigation. Additionally, sampling bias were reduced with regard to environmental conditions, only one sample was kept when replicated. Each sampling site was converted into geographic coordinates (World Geodetic System 1984 data) by ArcGIS (ver. 10.2) (http://www.esri.com/). Finally, a total of 1808 points were valid, and the samples points were mainly from China, Mexico, United States and South Africa, etc. (Fig. 1; Additional file 1: Table S1) [16-26].

\section{Environmental variables}

Following the main controlling factors of the distribution and characteristics of medicinal plants, the prediction of model selection of variables should reflect the coldest and warmest temperatures, moisture, radiation and precipitation of species, and the most influential variables associated with diosgenin yield are considered as well [15]. In this study, the selection of mainly used variables was based on the biological characteristics of medicinal plants, references and the data analysis [13-15, 27, 28]. A total of six related ecological factors for medicinal plants were selected and down from the Worldclim database (http://www.worldclim.org/) (Period 1970-2000) (Additional file 1: Table S2) [29, 30], with a resolution of 2.5 arcmin-seconds, and availability of data of 10 Dioscorea species were in supply files (Additional file 2). The soil variables were obtained from Harmonized World Soil Database (http://www.iiasa.ac.at/). For region measurements, the layers were projected into UTM coordinates with the original data in WGS84. Global administrative areas come from the GADM database, and the version is 2.8 (http://www.gadm.org/).

\section{Species distribution modeling}

GMPGIS was a model using global geographic information system for medicinal plant distribution prediction, and it was self-developed by the Institute of Chinese Materia Medica, China Academy of Chinese Medical Sciences (CACMS) based on GIS technology. GMPGIS climate database was adopted from the World Clim-Global Climate Data [29] and CliMond (https:// www.climond.org/), and the soil database was obtained from Harmonized World Soil Database (HWSD) [1315]. In GMPGIS, the occurrences of plant species with known distributions are related to climate data by using improved k-means method in Euclidean distances algorithms, and the accuracy of GMPGIS model has been 


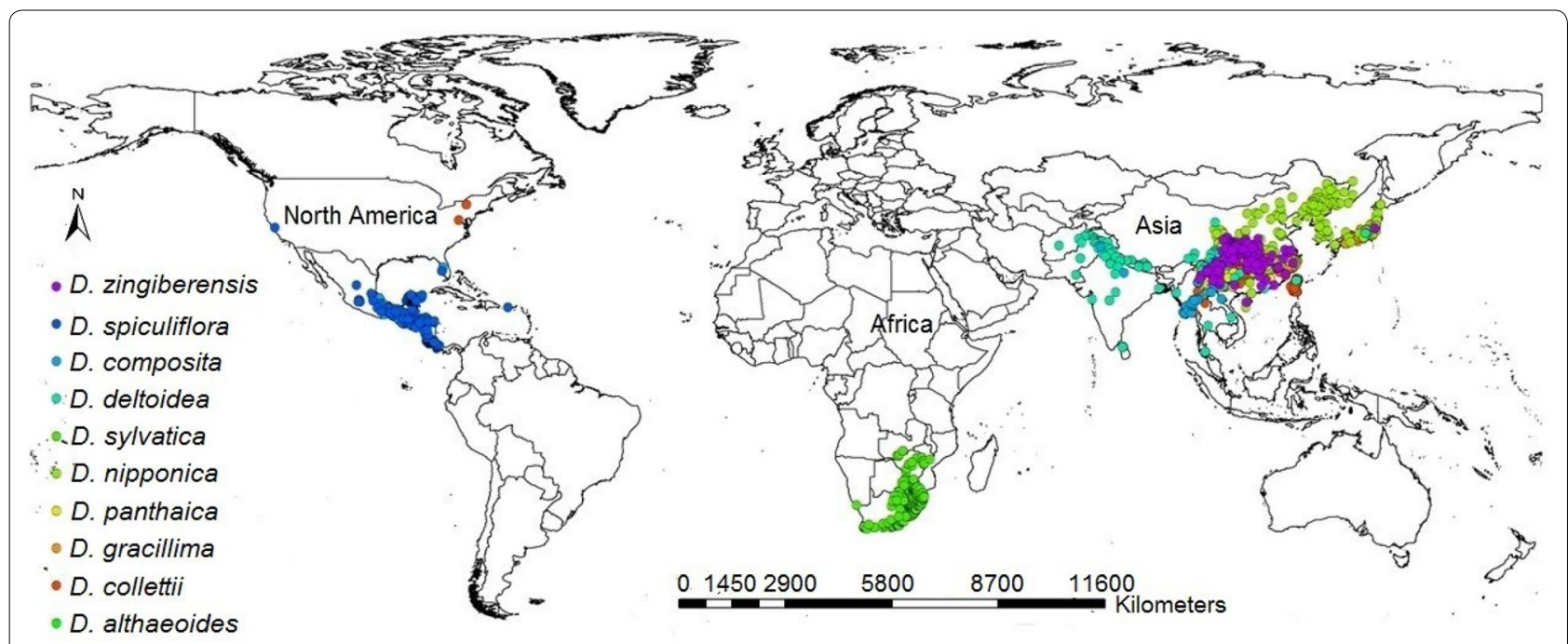

Fig. 1 Global spatial distribution of occurrence records of diosgenin-contained Dioscorea species around the world. The map was plotted using ArcGIS 10.2 (http://www.esri.com/)

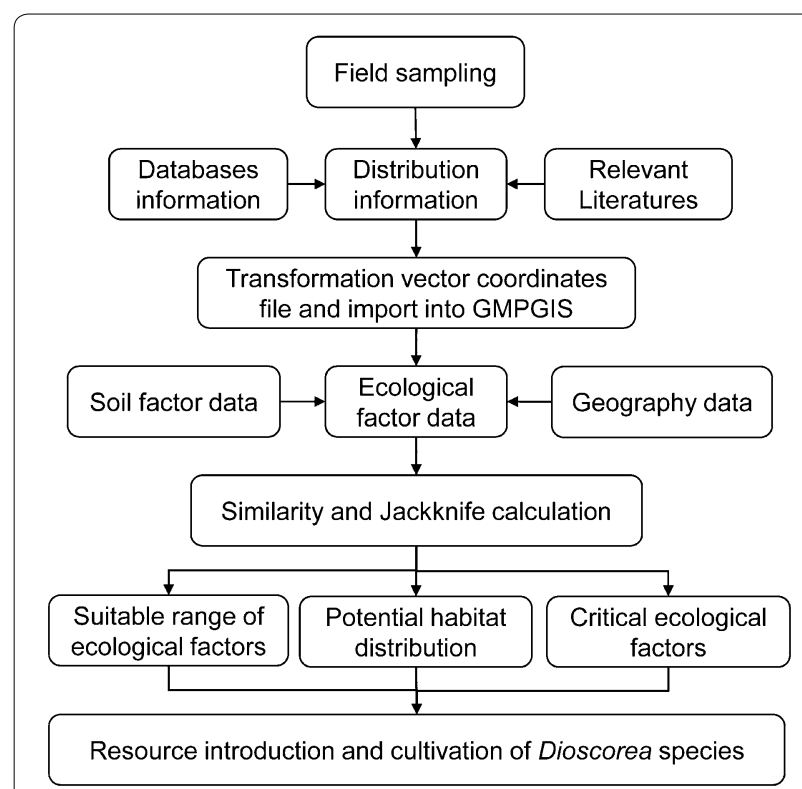

Fig. 2 Flow-chart of the ecological suitability analysis for diosgenin-contained Dioscorea species

successfully verified by six Panax plants [14, 15]. A suitable habitat map for Dioscorea species was established according to the following four main steps: linear normalization (a), grid-based spatial clustering, vectorbased overlaying and suitable region analysis (b and $c$ ). The suitable soil layer and climatic factors in the Euclidean distance layer were intersected, and the predicted map was drawn [13, 15] (Fig. 2). A natural probabilistic explanation representing degrees of ecology suitability
$(0=$ unsuitable to $0.999=$ best habitat $)$ was presented by the model logistic outcomes [31].

$$
\begin{aligned}
& v_{i}^{\prime}=\frac{v_{i}-\min _{A}}{\max _{A}-\min _{A}} \times 100, \\
& E=\sum_{i=1}^{k} \sum_{p \in D_{i}} \operatorname{dist}\left(p, d_{i}\right)^{2},
\end{aligned}
$$

$$
\begin{aligned}
\operatorname{dist}\left(p, d_{i}\right)= & \operatorname{IF}\left[\min \leq v_{i} \leq \max , 0\right. \\
& \left.\min \left(\mid v_{i}^{\prime}-\text { newmin }_{A}|,| v_{i}^{\prime}-\text { newmax }_{A} \mid\right)\right]
\end{aligned}
$$

where ( $v i)$, the $v i$ of $A$ to $v i$ in the range [newminA, new$\max A]$, and $d i$ is the scope of cluster $D i$, newminA is the minimum value after normalizing the layer, newmaxA is the maximum value after normalizing the layer.

In this research, analysis of the key environmental variables which constrained the geographical distribution of Dioscorea species were conducted by jackknife testing in MaxEnt version 3.3.3 k [32]. Parameter setting of modeling was as follows: The training set was $75 \%$ of the sampling data points. For the test set, $25 \%$ residual was used to examine the predictive ability of the MaxEnt, and the jackknife was used to test the weight. In order to prevent over-fitting of the test data, the regularization multiplier value was set as 1 , and convergence threshold 0.00001 [33]. All other settings were kept as default value and output format settings [34]. 


\section{Phylogenetic relationship among Dioscorea species}

The chloroplast genomes mat $K$ and $r b c L$ sequence possessed highly interspecific differences and were capable of distinguishing medicinal plants at the species level [35]. In the present study, mat $K$ and $r b c L$ sequences of ten diosgenin of Dioscorea species were downloaded from the GenBank database. Consensus sequences and coting generation were obtained by the software CondonCode Aligner V3.7.1 (CodonCode Co., USA). The sequences of Dioscorea species were aligned by Muscle, and the genetic distance was computed with MEGA6.0 software (http://www.megasoftware.net) by using K2P model [36]. A phylogenetic tree based on matK and $r b c L$ was constructed by employing the neighbor-joining (NJ) tree method, and bootstrap tests were calculated with 1000 resamples to assess the statistical confidence in phylogenetic analysis. Accordance with the phylogenetically related genetic information inferred from APGIV, and same sequence of Tacca chantieri Andre and Alisma plantago-aquatica Linn downloaded from GenBank were chosen as our group when the NJ tree was built [37-39] (Additional file 1: Table S3). The Minimum Standards of Reporting Checklist contains details of the experimental design, and statistics, and resources used in this study (Additional file 3).

\section{Results}

Model performance and contribution of environmental variables

$D$. deltoidea and $D$. nipponica showed a significantly different performance in regions and climatic factors comparing to all the other species (Table 1, Additional file 4: Figure S1). D. deltoidea and D. composita variation of climatic factors were the maximum and minimum, respectively. In six climatic factors, the maximal variation factor was T-warm, while the minimal change factor was T-cold. Soil types of ten Dioscorea species were mainly in Acrisols, Alisols, Andosols, Anthrosols, Cambisols, Fluvisols, and so on. Thus, the results indicated that these ecological conditions were optimal for the growth of diosgenin-contained Dioscorea species.

The contributions of each ecological factor were revealed by Jackknife test (Fig. 3). According to the result, annual precipitation and annual mean radiation were the key factors driving the modelled distribution of most of the ten Dioscorea species. For four of the taxa (D. zingiberensis, D. sylvatica, D. spiculiflora and D. nipponica), radiation emerged as an important contributor to the modelled distribution, as well as precipitation probability for other three taxa $(D$. composita, $D$. deltoidea and $D$. panthaica), humidity for D. gracillima and T-cold for $D$.

Table 1 Range values (minimum-maximum) of the ecological factors for ten diosgenin-contained Dioscorea species

\begin{tabular}{|c|c|c|c|c|c|c|}
\hline Species & T-aver $\left({ }^{\circ} \mathrm{C}\right)$ & T-warm $\left({ }^{\circ} \mathrm{C}\right)$ & $\mathrm{T}$-cold $\left({ }^{\circ} \mathrm{C}\right)$ & Precipitation $(\mathrm{mm})$ & Radiation $\left(\mathrm{W} \mathrm{m}^{-2}\right)$ & Humidity (\%) \\
\hline \multirow[t]{2}{*}{ D. althaeoides } & 4.80 to 21.50 & 12.00 to 28.50 & -4.10 to 14.20 & 347 to 1736 & 125.58 to 153.30 & 41.90 to 76.40 \\
\hline & \multicolumn{6}{|c|}{ Soil types: Acrisols, Alisols, Andosols, Anthrosols, Chernozems etc. } \\
\hline \multirow[t]{2}{*}{ D. collettii } & 4.40 to 27.20 & 10.90 to 29.30 & -4.10 to 26.20 & 543 to 4854 & 119.08 to 168.05 & 50.20 to 77.00 \\
\hline & \multicolumn{6}{|c|}{ Soil types: Acrisols, Alisols, Anthrosols, Cambisols, Fluvisols etc. } \\
\hline \multirow[t]{2}{*}{ D. composita } & 12.40 to 27.20 & 13.30 to 32.80 & 4.80 to 25.20 & 785 to 4143 & 136.80 to 198.97 & 51.60 to 78.10 \\
\hline & \multicolumn{6}{|c|}{ Soil types: Acrisols, Andosols, Arenosols, Cambisols, Fluvisols etc. } \\
\hline \multirow[t]{2}{*}{ D. deltoidea } & -6.70 to 28.10 & 4.20 to 34.10 & -18.20 to 26.1 & 142 to 3774 & 122.83 to 228.01 & 38.40 to 76.50 \\
\hline & \multicolumn{6}{|c|}{ Soil types: Acrisols, Andosols, Arenosols, Cambisols, Fluvisols etc. } \\
\hline \multirow[t]{2}{*}{ D. gracillima } & 2.00 to 19.50 & 13.20 to 28.70 & -18.70 to 10.3 & 543 to 2821 & 116.73 to 144.76 & 56.80 to 76.40 \\
\hline & \multicolumn{6}{|c|}{ Soil types: Acrisols, Alisols, Andosols, Anthrosols, Cambisols etc. } \\
\hline \multirow[t]{2}{*}{ D. nipponica } & -1.70 to 25.90 & 5.60 to 28.80 & -20.30 to 220 & 295 to 3338 & 113.89 to 165.42 & 47.60 to 76.80 \\
\hline & \multicolumn{6}{|c|}{ Soil types: Acrisols, Alisols, Andosols, Arenosols, Anthrosols etc. } \\
\hline \multirow[t]{2}{*}{ D. panthaica } & 6.20 to 20.30 & 13.20 to 27.50 & -3.50 to 15.10 & 543 to 1743 & 122.15 to 154.77 & 50.20 to 75.70 \\
\hline & \multicolumn{6}{|c|}{ Soil types: Acrisols, Alisols, Anthrosols, Cambisols, Fluvisols, etc. } \\
\hline \multirow[t]{2}{*}{ D. spiculiflora } & 11.20 to 27.10 & 13.10 to 29.30 & 9.00 to 26.30 & 344 to 4296 & 150.92 to 207.56 & 46.50 to 80.50 \\
\hline & \multicolumn{6}{|c|}{ Soil types: Acrisols, Andosols, Cambisols, Gleysols, Kastanozems etc. } \\
\hline \multirow[t]{2}{*}{ D. sylvatica } & 6.20 to 24.00 & 10.40 to 26.40 & 1.20 to 20.20 & 68 to 1600 & 161.28 to 206.69 & 46.00 to 73.80 \\
\hline & \multicolumn{6}{|c|}{ Soil types: Acrisols, Arenosols, Calcisols, Cambisols, Fluvisols etc. } \\
\hline \multirow[t]{2}{*}{ D. zingiberensis } & 7.40 to 24.20 & 16.60 to 28.70 & -3.50 to 18.80 & 543 to 1849 & 117.70 to 150.39 & 52.90 to 76.00 \\
\hline & \multicolumn{6}{|c|}{ Soil types: Acrisols, Alisols, Andosols, Anthrosols, Cambisols etc. } \\
\hline
\end{tabular}




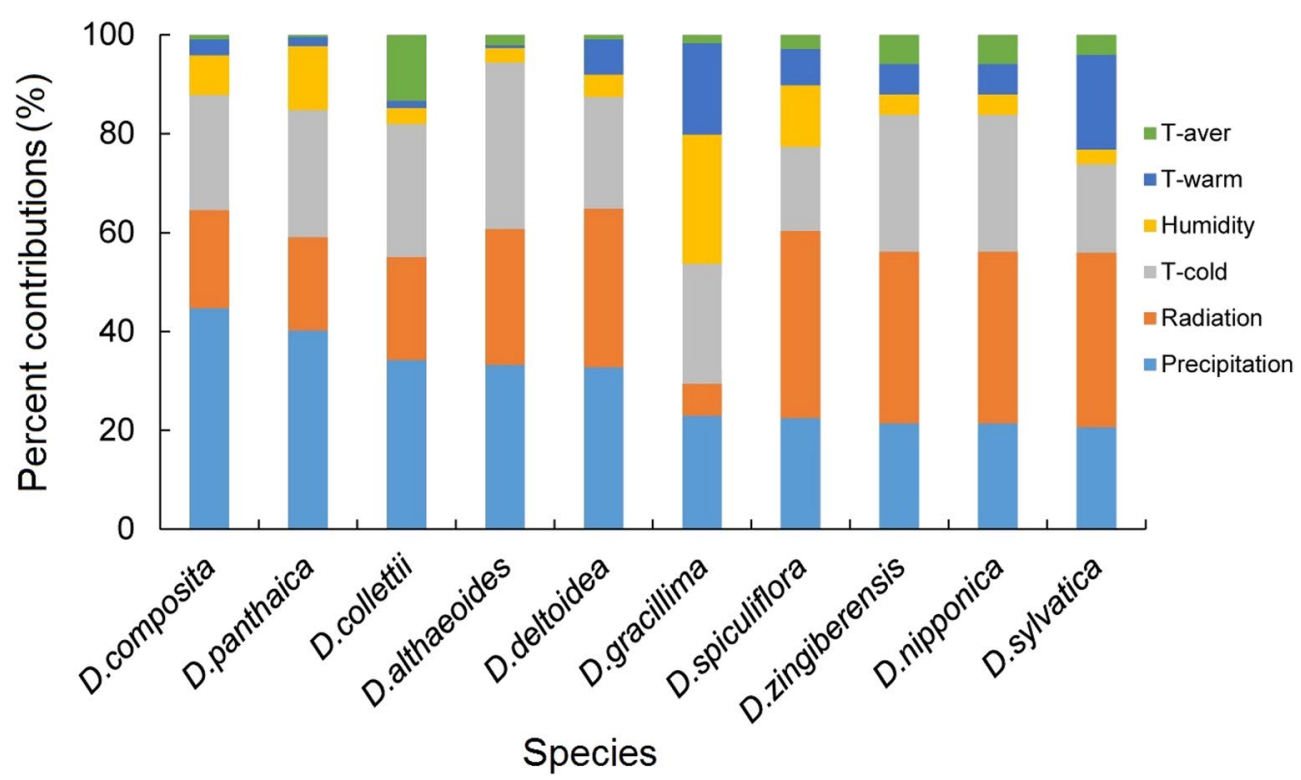

Fig. 3 Contribution of individual variable to habitat suitability allowing the diosgenin-contained Dioscorea species

althaeoides. The T-cold was also an important contributor to the modelled distribution in whole species, except for the D. spiculiflora, D. deltoidea and D. sylvatica. None of the species was strongly constrained by T-aver or T-warm. The range of suitable environmental factors provided a useful reference for the cultivation of those ten Dioscorea species.

\section{Potential global distribution}

According to ecological similarity growth of Dioscorea species, the results showed that the potential distribution areas of ten Dioscorea species stretched a rather wide area (Fig. 4, Additional file 1: Table S4). Ecological range of $D$. deltoidea, $D$. collettii, D. composita and D. spiculiflora covered a wide field, and the potential areas were more than $(158.16-465.91) \times 10^{5}$ $\mathrm{km}^{2}$, mainly distributed in the central region of South America, southern part of Africa and Asia (Fig. 4a, c-e). D. nipponica was potentially distributed in most parts of the earth, but mainly in most parts of North America, southern part of Europe and the eastern part of Asia, and suitable areas were $262.33 \times 10^{5} \mathrm{~km}^{2}$ (Fig. 4b). D. sylvatica was mainly potentially distributed in southern part of Africa, South America and Asia, and potentially suitable areas are $107.40 \times 10^{5}$ $\mathrm{km}^{2}$ (Fig. 4f). In contrast, the potential areas of $D$. althaeoides, D. zingiberensis, D. gracillima and D. panthaica areas were within the scope of (59.02$68.37) \times 10^{5} \mathrm{~km}^{2}$, and mainly distributed in the eastern part of North America, southern part of European and Asia (Fig. $4 \mathrm{~g}-\mathrm{j}$ ). Based on the area of producing district, there were some countries suitable for promoting planting such as China, Mexico, United States, Brazil, France, Japan, North Korea, Indonesia, India, Australia and so on (Additional file 4: Figure S2). The results indicated that $D$. deltoidea, $D$. nipponica and $D$. collettii were proper plantations in Eastern Asia; $D$. deltoidea, D. composita and D. spiculiflora were proper plantation in North America; the proper plantation species in Southern Africa contained D. deltoidea and $D$. sylvatica, and D. spiculiflora were suitable cultivation in North America (Fig. 5). The suitable areas in Southern Europe and Oceania seemed limited, and the proper species were $D$. deltoidea and $D$. nipponica. Asia was found to be the largest planting area, and Oceania, the smallest.

\section{Phylogenetic relationships among ten Dioscorea species}

Phylogenetic trees of ten diosgenin-contained species from Dioscorea were created by the NJ method. The result of the analysis on the bootstrap values above $50 \%$ is given (Fig. 6). The tree was derived by alignment of concatenation mat $K$ and $r b c L$ sequences. The moderately and strongly supported groups of phylogenetic trees were clearly shown to be two trees. Among ten Dioscorea species, two North America species of D. spiculiflora and D. composita and one African species $D$. sylvatica belonged to the same cluster (Cluster I), six Asian species such as $D$. gracillima, D. althaeoides, D. panthaica, D. deltoidea, $D$. zingiberensis and $D$. nipponica formed a moderate support to the same cluster (Cluster II). As expected, 

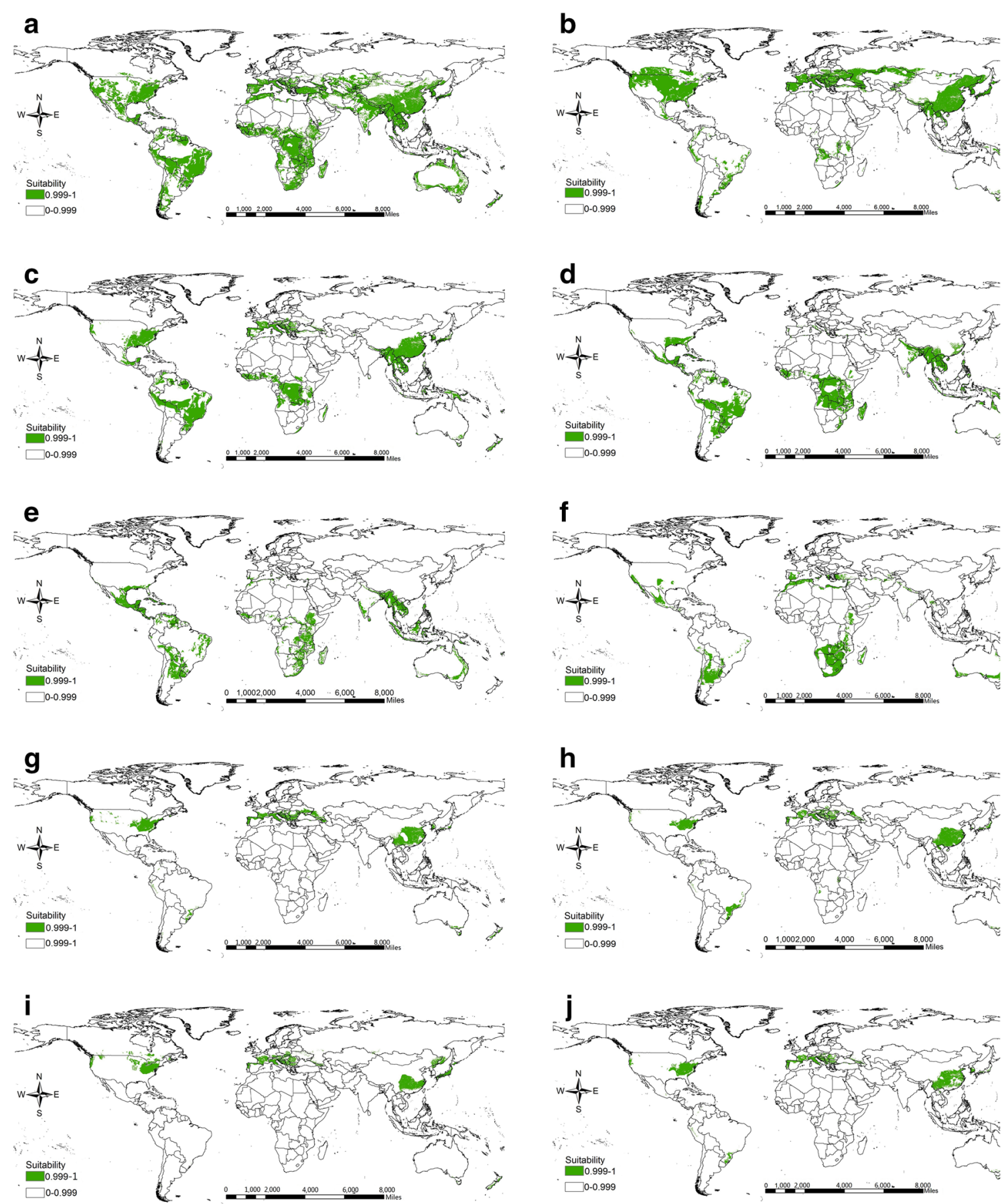

Fig. 4 Maximum similarities of the (left side) ecological distribution and (right side) suitable areas for diosgenin-contained species from Dioscorea. a D. deltoidea, b D. nipponica, $\mathbf{c}$ D. collettii, $\mathbf{d}$ D. composita, e D. spiculiflora, $\mathbf{f} D$. sylvatica, $\mathbf{g} D$. althaeoides, $\mathbf{h}$ D. zingiberensis, $\mathbf{i}$ D. gracillima, $\mathbf{j} D$. panthaica

D. collettii and the six species above were in one group together. As can be evaluated from the branch length, the evolutionary divergence between two groups was significant, the outgroup were Tacca chantieri Andre and Alisma plantago-aquatica Linn.

\section{Discussion}

In recent years, species distribution models (SDMs) developed to be a significant tool to estimate the impact of climate change on plant distribution [40, 41]. These models formed a correlation between species 

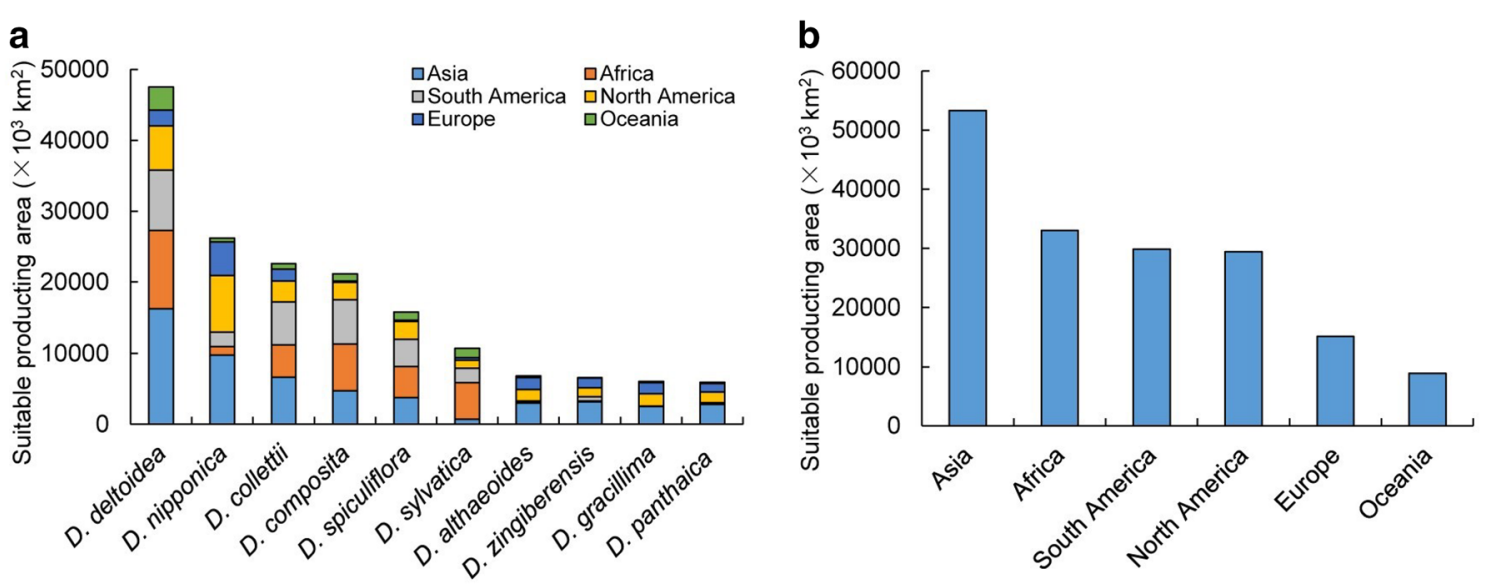

Fig. 5 Results of diosgenin-contained plants of ten Dioscorea species for suitable regions area in continents worldwide based on GMPGIS. a Suitable producing area of species, $\mathbf{b}$ suitable producing area of each continent

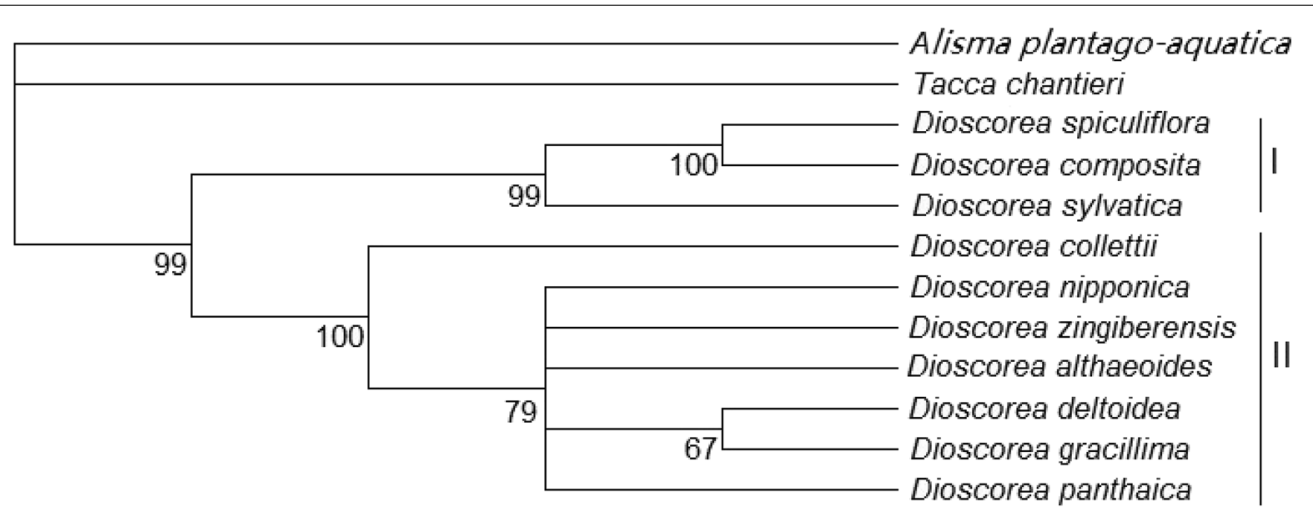

Fig. 6 Neighbor-joining tree of the matK and rbcL genes from accessions belonged to Dioscorea Numbers at the nodes indicate bootstrap values (\% over 1000 replicates). I (African and North America species) II (Asia species)

existence and its geophysical environment to predict the current potential distribution of species [42, 43]. GMPGIS is a model capable of indicating the range of ecological factors and the suitable potential ecological areas simply by running a relatively small number of present data, presenting accuracy in predicting suitable region of plants, such as Panax ginseng, Panax japonicas $[14,15]$. In this study, sample points from 108 to 274 of ten higher diosgenin-contained Dioscorea species were used in GMPGIS, the model suggested that the potentially suitable areas of Dioscorea species shared similarity distribution with occurrence dataset of ten species [21,22], and some unknown potential areas were predicted in our study. Those data reiterated the conclusion of GMPGIS, which indicated that it was a viable accuracy method for modelling plant distributions. Consequently, the combination of GMPGIS and jackknife test will play a dominate role in the prediction of suitable areas for medicinal species protection and cultivation.

Generally, environmental factors are the ones to blame for the driving forces of changes in Dioscorea species distribution and various ecological factors contribute to the growth of different species [15]. Most researches declared that Dioscorea species should be cultivated in high-temperature and fertile soil sandy loam, and its growth was determined by water shortage, strong light radiation and cold injury [44-46]. Therefore, summarizing the suitable climate factor of Dioscorea species distribution could provide a scientific basis for high-quality plants cultivation. This study found that the annual precipitation and annual mean radiation were the key factors driving the Dioscorea species distribution according to environment variable contributions. These results were confirmed by the results from current ecological feature study on Dioscorea species distribution. Seven Dioscorea 
species are distributed in Sichuan basin, China, and those plant species require a relatively damp habitat with low radiation to grow [45]. Previous studies on the relationship between effective constituent and ecological factors suggested that precipitation and radiation were the principal ecological factors affecting the diosgenin accumulated from Dioscorea species [47], and similarities or differences in growth habits could lead to different yields and qualities. Besides, the variety in annual mean radiation could also influence photosynthesis, and further affect the grow stage of diosgenin-contained Dioscorea species [48]. The results of this study proved a similar correlation between ecological factors and cultivation. In conclusion, during the process of introduction and cultivation of diosgenin plants, it is necessarily needed to make scientific plant management according to various suitable environmental conditions of Dioscorea species.

It seems fundamental to detect the potential distribution regions for the conservation and plantation of medicinal plants [49]. In this study, the modelled ecological niches and geographic distributions of these ten diosgenin-contained Dioscorea species showed a high degree of differentiation. The potential suitable areas of three Asia Dioscorea species (D. deltoidea, D. nipponica and $D$. collettii) were mainly located in the mideast region of North America and South America, southern part of Africa and eastern part of Asia, and the potential global distributions were within the scope of (226.23-465.91) $\times 10^{5} \mathrm{~km}^{2}$. However, the other four Asia Dioscorea species (D. zingiberensis, D. panthaica, $D$. althaeoides and D. gracillima) were mainly potentially distributed in China, the United States and southern areas of Europe, and the potential suitable areas were within the scope of $(59.02-68.37) \times 10^{5} \mathrm{~km}^{2}$. It indicated that some of Dioscorea species were distributed within a very narrow region, whereas other taxa were widely distributed in the world. Perhaps genetic information is one of the most significant causes to determine the distribution of Dioscorea species. Consequently, to select "where to plant or grow" the primary thing to do before the introduction and cultivation of diosgenin plant.

Our model results indicated that diosgenin-contained Dioscorea species could be introduced to many undiscovered potential areas, such as south of Europe and central north of America, except for the original production regions of Dioscorea above. According to the diosgenin contents and potential distribution, $D$. deltoidea and $D$. nipponica were recommended plants in the Asia. D. deltoidea and D. sylvatica were suggested being planted in Africa, D. composita and D. spiculiflora were suitable to be cultivated in North America. Potential suitable regions prediction in this study could provide a scientific basis for Dioscorea species selection, as well as the introduction and cultivation worldwide. However, a field test is necessary before Dioscorea species cultivation in large areas, since the production would be affected by many other factors, such as local transport, natural disaster, and so on.

Phylogenetic trees of ten Dioscorea species were created by NJ methods. Among those species, seven from Asia formed a moderately supported group belonging to the same cluster. Three species of $D$. spiculiflora, $D$. composita and D. sylvatica belonged to another cluster, which came from Africa and North America. Previous studies showed that the Hengduan Mountains of China was a distributing center of Dioscorea species, and it also demonstrated a suitable potential area for Dioscorea species introduction and cultivation in this research [3]. Shen et al. reported seed traits character of Haloxylon ammodendron was strongly affected by climatic and geographical factors, and were moderately correlated with genetic diversity [50]. This study indicated that distribution region of species was correlated to its genetics and environment, and these potential suitable regions could introduce and cultivate Dioscorea species in the future.

Containing diosgenin, Dioscorea species owns a fine cultivated character and high reproduction, so the plantation scale of Dioscorea species in recent years has expanded constantly. However, cultivation distribution and ecological requirements of Dioscorea species remain chaotic and is in need of universal unification globally, yet confusion in its introduction and cultivation has led to a decline in yield and quality of diosgenin [7]. Our research result will provide a practical reference for the production of diosgenin in different areas worldwide. Combining with the research result, the plantation development directions of diosgenin-contained Dioscorea species in the future are (1) selecting suitable diosgenin species in accordance with the research results to conduct plantation; (2) strengthening ecological study on the quality of Dioscorea species, studying ecological characteristics of main cultivated species, and analyzing the influencing mechanism of environmental factors, such as light, temperature and water on the content and yield of diosgenin; (3) to develop a new variety of high-quality and stressresistant Dioscorea species in the future.

\section{Conclusions}

In this study, a large occurrence dataset of diosgenincontained Dioscorea species were obtained from Eastern Asia, Southern North America and Southern Africa. Results showed the potential distribution of these Dioscorea species presented a higher degree of differentiation, and that new ecological suitability areas were mainly distributed in the central region of South America, the southern part of the European and coastal 
region of Oceania. The annual precipitation and annual mean radiation were the important climatic factors controlling the distribution of those Dioscorea species. The suitable areas and assessment of climatic factors will serve as a useful reference for the conservation, introduction and cultivation of diosgenin Dioscorea plants in ecological suitable areas.

\section{Additional files}

Additional file 1: Table S1. Sample points and numbers of ten diosgenin-contained Dioscorea species. Table S2. Bioclimatic variables used as predictors in this study. Table S3. GenBank accessions of matK and rbcL sequences from Dioscorea and outgroup species. Table S4. Potential distribution sites and areas of diosgenin-contained Dioscorea species around the world $\left(\times 10^{5} \mathrm{~km}^{2}\right)$.

Additional file 2. Bioclimatic variables of 10 diosgenin-contained Dioscorea species.

Additional file 3. Minimum standards of reporting checklist.

Additional file 4: Figure S1. Boxplots are showing the percentage of stable habitat data of diosgenin-contained Dioscorea species under climate change models. Figure $\mathbf{S 2}$. Suitable areas for diosgenin-contained species from Dioscorea.

\section{Authors' contributions}

LXW and CSL conceived and designed the study. SL and XJ collected and performed the data analysis. SL, XJ, LL, HHY and MXX wrote the manuscript. All authors are responsible for reviewing data. All authors read and approved the final manuscript.

\section{Acknowledgements}

This study is supported and sponsored by the National Science-technology Support Plan Project (Grant No. 2015BAI05B02), Project supported by the China Postdoctoral Science Foundation (Grant No. 2017M611128).

\section{Competing interests}

The authors declare that they have no conflict of interest.

\section{Availability of data and materials}

The readers can use data and materials in this manuscript by quotation of author names and Journal of Chinese Medicine.

\section{Consent for publication}

All of authors consent to publication of this study in Journal of Chinese Medicine.

\section{Ethics approval and consent to participate}

Not applicable.

\section{Funding}

Project supported by the National Science-technology Support Plan Project (Grant No. 2015BAI05B02), Project supported by the China Postdoctoral Science Foundation (Grant No. 2017M611128).

\section{Publisher's Note}

Springer Nature remains neutral with regard to jurisdictional claims in published maps and institutional affiliations.

Received: 26 September 2018 Accepted: 15 November 2018 Published online: 19 November 2018

\section{References}

1. Li X, Ma JZ, Shi YD. Research progress and prospects of dioscorea and diosgenin. Chem Ind For Prod. 2010;30(2):107-12.

2. Nie LH, Lin SZ, Ning ZY. Research progress of diosgenin from Dioscorea plants. Chin J Biochem Pharm. 2004;25(5):318-20.

3. Wan JR, Ding ZZ, Qin HZ. A phytogeographical study on the family Dioscoreaceae. Acta Bot Boreal-Occident Sin. 1994;14(2):128-35.

4. Yi T, Fan LL, Chen HL, Zhu GY, Suen HM, Tang YN, Zhu L, Chu C, Zhao ZZ, Chen HB. Comparative analysis of diosgenin in Dioscorea species and related medicinal plants by UPLC-DAD-MS. BMC Biochem. 2014;15:19.

5. Chaturvedi HC, Jain M, Kidwai NR. Cloning of medicinal plants through tissue culture-a review. Indian J Exp Biol. 2007;45(11):937-48.

6. Sautour M, Mitaine-Offer AC, Lacaille-Dubois MA. The Dioscorea genus, a review of bioactive steroid saponins. J Nat Med. 2007;61 (2):91-101.

7. Liu P, Guo SL, Lv HF, Xie XW, Wu XY. A summary of the study on Chinese Dioscorea. J Zhejiang Nornal Univ (Nat. Sci). 1993;16(4):100-6.

8. Dansi A, Mignouna HD, Zoundjihekpon J, Sangare A, Asiedu R, Quin FM. Morphological diversity cultivar groups and possible descent in the cultivated yams Dioscorea cayenensis, D. rotundata) complex in Benin Republic. Genet Resour Crop Ev. 1999;46(4):371-88.

9. Ondo ovono P, Kevers C, Dommes J. Effects of planting methods and tuber weights on growth and yield of yam cultivars (Dioscorea rotundata Poir.) in Gabon. Int Res J Agr Sci. Soil Sci. 2016;6(3):32-42.

10. Viruel J, Catalán P, Segarra-Moragues JG. Latitudinal environmental niches and riverine barriers shaped the phylogeography of the central Chilean endemic Dioscorea humilis Dioscoreaceae). PLOS ONE. 2014;9(10):e110029

11. Wang Z, Li B, Xiao JL, Jiang DC. Regionalization study of Dioscorea nipponica in Jilin province based on MaxEnt and ArcGIS. China J Chin Mater Med. 2017:42(22):4373-7.

12. Irfan-Ullah M, Amarnath G, Murthy MSR, Peterson AT. Mapping the geographic distribution of Aglaia bourdillonii Gamble (Meliaceae) an endemic and threatened plant using ecological niche modeling. Biodivers Conserv. 2006;16(6):1917-25.

13. Chen SL. Analysis on ecological suitability and regionalization of traditional Chinese medicinal material. 2nd ed. Beijing: Science Press; 2017.

14. Shen L, Wu J, Li XW, Xu J, Dong LL, Sang MC, Sun CZ, Fujiharas L, Chen SL. A study of global ecological adaptability and field selection practices of Panax ginseng. China J Chin Mater Med. 2016;41(18):3314-22.

15. Du ZX, Wu J, Meng XX, Li JH, Huang LF. Predicting the global potential distribution of four endangered Panax species in middle-and low-latitude regions of china by the geographic information system for global medicinal plants (GMPGIS). Molecules. 2017;22(10):1630.

16. Li BG. Research and industrial development of Chinese medicinal plant resources of Dioscorea. Beijing: Science press; 2006.

17. Singh KN, Kaushal R. Comprehensive notes on commercial utilization characteristics and status of steroid yielding plants in India. Ethnobot Leaflets. 2007;11:45-51.

18. Avula B, Wang YH, Ali Z, Smillie TJ, Khan IA. Chemical fingerprint analysis and quantitative determination of steroidal compounds from Dioscorea villosa, Dioscorea species and dietary supplements using UHPLC-ELSD. Biomed Chromatogr. 2014;28(2):281-94.

19. Viruel J, Segarra-Moraques JG, Raz L, Forest F, Wilkin P, Sanmartin I, Catalan P. Late cretaceous-early eocene origin of yams (Dioscorea Dioscoreaceae) in the Laurasian Palaearctic and their subsequent Oligocene-Miocene diversification. J Biogeogr. 2016;43(4):750-62.

20. Thapyai C, Wilkin P, Chayamarit K. The Dioscorea species of Doi Chiang Dao with particular reference to Dioscorea collettii Hook. f. Dioscoreaceae) a new record for northern Thailand. Thai Fort Bull Bot. 2005;33:213-9.

21. Tang SR, Yang RT, Pan FS, Zhao AM, Pang ZJ. Steroidal saponin and steroidal sapogenin in Chinese Dioscorea L. J Plant Resour Environ. 2007;16(2):64-72

22. Hsu KM, Tsai JL, Chen MY, Ku HM, Liu SC. Molecular phylogeny of Dioscorea (Dioscoreaceae) in East and Southeast Asia. Blumea-Biodivers Evol Biogeogr Plant. 2013;58(1):21-7.

23. Yang $L Y, X u Z Z$, Chen $C$, Lv LF, Zhao Q, Yuan LC. A preliminary report on the domesitic cultivation experiment of Dioscorea deltoidea. Southwest China J Agr Sci. 2006;19(Suppl 1):218-21.

24. Cho J, Choi H, Lee J, Kim MS, Sohn HY, Lee DG. The antifungal activity and membrane-disruptive action of dioscin extracted from Dioscorea nipponica. BBA-Biomembranes. 2013;1828(3):1153-8. 
25. Sun HQ, Luo K, Zou WJ, PsbA-trnH Deng SY. Fragment Sequence Analysis of Dioscorea nipponica D. panthaica and D. zingiberensis. Chin J Appl Environ Biol. 2006;12(6):792-7.

26. Blunden G, Hardman R, Hind FJ. The comparative morphology and anatomy of Dioscorea sylvatica Eckl. from Natal and the Transvaal. Bot J Linn Soc. 2008;64(4):431-46

27. Pan RZ. Plant physiology. 7th ed. Beijing: Higher Education Press; 2012.

28. Zhang X, Meng XX, Wu J, Huang LF, Chen SL. Global ecological regionalization of 15 Illicium species: nature sources of shikimic acid. CHIN MEDUK. 2018;13(1):31

29. Hijmans RJ, Cameron SE, Parra JL, Jones PG, Jarvis A. Very high resolution interpolated climate surfaces for global land areas. Int J Climatol. 2005;25:1965-78.

30. Kriticos DJ, Webber BL, Leriche A, Ota N, Macadam I, Bathols J, Scott JK. CliMond: global high-resolution historical and future scenario climate surfaces for bioclimatic modelling. Methods Ecol Evol. 2012;3(1):53-64.

31. Pearson RG, Raxworthy CJ, Nakamura M, Peterson AT. Predicting species distributions from small numbers of occurrence records, a test case using cryptic geckos in Madagascar. J Biogeogr. 2010;34(1):102-17.

32. Phillips SJ, Dudík M. Modeling of species distributions with Maxent, new extensions and a comprehensive evaluation. Ecography. 2008;31(2):161-75.

33. Elith J, Phillips SJ, Hastie T, Dudík M, Chee YE, Yates CJ. A statistical explanation of MaxEnt for ecologists. Divers Distrib. 2011;17(1):43-57.

34. Phillips SJ, Anderson RP, Schapire RE. Maximum entropy modeling of species geographic distributions. Ecol Model. 2006;190(3):231-59.

35. Uchoi A, Malik SK, Choudhary R, Kumar S, Rohini MR, Pal D, Ercisli S, Chaudhury R. Inferring phylogenetic relationships of indian Citron Citrus medica L.) based on rbcL and matK sequences of chloroplast DNA. Biochem Genet. 2016;54(3):249-69.

36. Zinger $\mathrm{L}$, Philippe $\mathrm{H}$. Coalescing molecular evolution and DNA barcoding Mol Ecol. 2016;25(9):1908-10.

37. Li DZ, Gao LM, Li HT, Wang H, Ge XJ, Liu JQ, et al. Comparative analysis of a large dataset indicates that internal transcribed spacer (ITS) should be incorporated into the core barcode for seed plants. Proc Natl Acad Sci USA. 2011;108(49):19641-6.

38. Chen ZD, Yang T, Lin L, Lu LM, Li HL, Sun M, et al. Tree of life for the genera of Chinese vascular plants. J Syst Evol. 2016:54(4):277-306.
39. Chase MW, Soltis DE, Olmstead RG, Morgan D, Les DH, Mishler BD, et al. Phylogenetics of seed plants: an analysis of nucleotide sequences from the plastid gene rbcL. Ann Mo Bot Gard. 1993;80(3):528-80.

40. Thomas CD, Cameron A, Green RE, Bakkenes M, Beaumont LJ, Collingham YC, et al. Extinction risk from climate change. Nature. 2004:427:114-45.

41. Thuiller W, Lavorel S, Araujo MB, Sykes MT, Prentice IC. Climate change threats to plant diversity in Europe. Proc Natl Acad Sci USA. 2005;102(23):8245-50.

42. Kumar S, Stohlgren TJ. MaxEnt modeling for predicting suitable habitat for threatened and endangered tree Canacomyrica monticola in New Caledonia. J Ecol Nat Environ. 2009;1 (1):94-8.

43. Elith J, Graham CH, Anderson RP, Dudik M, Ferrier S, Guisan A, et al. Ecological niche and species distribution modelling of sea stars along the Pacific Northwest continental shelf. Divers Distrib. 2016:22(12):1314-27.

44. Zhang SX, Zhou LY, Yu YJ. Study progress of Dioscorea nipponica Makino. Mol Plant Breed. 2005;3(1):107-11

45. Xu XD, Hu P, Wu H. Planting situation of Dioscorea Zingiberensis C.H Wright in Sichuan and strategy of industrialized development. Resour Devel Market. 2005;21(5):447-8.

46. Sun J, Li XM, Zhang J. Preliminary studies on the influence of light intensity on growth and saponin contents of Dioscorea zingiberensis. Acta Bot Boreal-Occident Sin. 2011;31(3):536-42.

47. Akula R, Ravishankar GA. Influence of abiotic stress signals on secondary metabolites in plants. Plant Signal Behav. 2011;6(11):1720-31.

48. Srivastava AK, Gaiser T, Paeth H, Ewert F. The impact of climate change on Yam (Dioscorea alata) yield in the savanna zone of West Africa. Agric Ecosyst Environ. 2012;153(24):57-64.

49. Qin AL, Liu B, Guo QS, Bussmann RW, Ma FQ, Jian Z, Xu GX, Pei SX. Maxent modeling for predicting impacts of climate change on the potential distribution of Thuja sutchuenensis Franch. An extremely endangered conifer from southwestern, China. Glob Ecol Conserv. 2017;10(C):139-46.

50. Shen L, Xu R, Liu S, Chen J, Xu CQ, Xie CX, Liu TN. Phenotypic variation of seed traits of Haloxylon ammodendron and its affecting factors. Biochem Syst Ecol. 2015;60:81-7.
Ready to submit your research? Choose BMC and benefit from:

- fast, convenient online submission

- thorough peer review by experienced researchers in your field

- rapid publication on acceptance

- support for research data, including large and complex data types

- gold Open Access which fosters wider collaboration and increased citations

- maximum visibility for your research: over $100 \mathrm{M}$ website views per year

At BMC, research is always in progress.

Learn more biomedcentral.com/submissions 